\title{
Indole and 2,4-Thiazolidinedione conjugates as potential anticancer modulators
}

\author{
Domenica M Corigliano $^{1}{ }^{\text {, }}$, Riyaz Syed ${ }^{2}$, Sebastiano Messineo ${ }^{1}$, Antonio Lupia ${ }^{1}$, Rahul Patel ${ }^{3}$, Chittireddy \\ Venkata Ramana Reddy ${ }^{2}$, Pramod K Dubey ${ }^{2}$, Carmela Colica ${ }^{4}$, Rosario Amato ${ }^{1}$, Giovambattista De Sarro ${ }^{1}$,

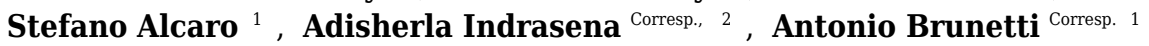 \\ 1 Department of Health Sciences, University "Magna Græcia" of Catanzaro, Catanzaro, Italy \\ 2 Department of Chemistry, Jawaharlal Nehru Technological University, Kukatpally, Hyderabad, India \\ 3 Department of Food Science and Biotechnology, Dongguk University, Ilsandong-gu, Goyang-si, Gyeonggi-do, South Korea \\ 4 CNR, IBFM UOS of Germaneto, University "Magna Græcia" of Catanzaro, Catanzaro, Italy \\ Corresponding Authors: Adisherla Indrasena, Antonio Brunetti \\ Email address: adisherla.indrasena@gmail.com, brunetti@unicz.it
}

Background: Thiazolidinediones (TZDs), also called glitazones, are five-membered carbon ring molecules commonly used for the management of insulin resistance and type 2 diabetes. Recently, many prospective studies have also documented the impact of these compounds as anti-proliferative agents, though several negative side effects such as hepatotoxicity, water retention and cardiac issues have been reported. In this work, we synthesized twenty-six new TZD analogues where the thiazolidinone moiety is directly connected to an N-heterocyclic ring in order to lower their toxic effects. Methods: By adopting a widely applicable synthetic method, twenty-six TZD derivatives were synthesized and tested for their antiproliferative activity in MTT and Wound healing assays with PC3 (prostate cancer) and MCF-7 (breast cancer) cells. Results: Three compounds, out of twenty-six, significantly decreased cellular viability and migration, and these effects were even more pronounced when compared with rosiglitazone, a well-known member of the TZD class of antidiabetic agents. As revealed by Western blot analysis, part of this antiproliferative effect was supported by apoptosis studies evaluating BCL-xL and C-PARP protein expression. Conclusion: Our data highlight the promising potential of these TZD derivatives as anti-proliferative agents for the treatment of prostate and breast cancer. 


\section{Indole and 2,4-Thiazolidinedione conjugates as potential anticancer modulators}

2

3 Domenica M. Corigliano $^{1,5}$, Riyaz Syed $^{2,5}$, Sebastiano Messineo $^{1}$, Antonio Lupia ${ }^{1}$, Rahul Patel ${ }^{3}$, 4 Chittireddy Venkata Ramana Reddy ${ }^{2}$, Pramod K. Dubey ${ }^{2}$, Carmela Colica ${ }^{4}$, Rosario Amato ${ }^{1}$, 5 Giovambattista De Sarro ${ }^{1}$, Stefano Alcaro ${ }^{1}$, Adisherla Indrasena ${ }^{2, *}$ and Antonio Brunetti ${ }^{1, *}$ 6

$7{ }^{1}$ Department of Health Sciences, University "Magna Græcia” of Catanzaro, Catanzaro, Italy

$8{ }^{2}$ Department of Chemistry, Jawaharlal Nehru Technological University Hyderabad, Kukatpally, 9 Hyderabad, India

$10{ }^{3}$ Dongguk University-Seoul, Department of Food Science and Biotechnology, Ilsandong-gu,

11 Goyang-si, Gyeonggi-do, Republic of Korea.

$12{ }^{4}$ CNR, IBFM UOS of Germaneto, University "Magna Graecia" of Catanzaro, Catanzaro, Italy 13

145 These authors contributed equally to this work

15

16 Corresponding authors:

17 Antonio Brunetti, brunetti@unicz.it

18 Adisherla Indrasena, adisherla.indrasena@gmail.com

19 


\section{ABSTRACT}

23 Background: Thiazolidinediones (TZDs), also called glitazones, are five-membered carbon ring

24 molecules commonly used for the management of insulin resistance and type 2 diabetes.

25 Recently, many prospective studies have also documented the impact of these compounds as

26 anti-proliferative agents, though several negative side effects such as hepatotoxicity, water

27 retention and cardiac issues have been reported. In this work, we synthesized twenty-six new

28 TZD analogues where the thiazolidinone moiety is directly connected to an N-heterocyclic ring

29 in order to lower their toxic effects.

30 Methods: By adopting a widely applicable synthetic method, twenty-six TZD derivatives were

31 synthesized and tested for their antiproliferative activity in MTT and Wound healing assays with

32 PC3 (prostate cancer) and MCF-7 (breast cancer) cells.

33 Results: Three compounds, out of twenty-six, significantly decreased cellular viability and

34 migration, and these effects were even more pronounced when compared with rosiglitazone, a

35 well-known member of the TZD class of antidiabetic agents. As revealed by Western blot

36 analysis, part of this antiproliferative effect was supported by apoptosis studies evaluating BCL-

$37 \mathrm{xL}$ and C-PARP protein expression.

38 Conclusion: Our data highlight the promising potential of these TZD derivatives as anti-

39 proliferative agents for the treatment of prostate and breast cancer. 


\section{INTRODUCTION}

48 Thiazolidinediones (TZDs) are a class of medicines commonly used alongside diet and exercise as therapeutic agents for the treatment of patients with type 2 diabetes mellitus, a disease in which defects in both peripheral insulin resistance and pancreatic beta cell insulin secretion coexist (1). Although used in clinical practice for many years, there is still much debate in the medical community about when TZDs should be recommended (2). The mechanism of action of TZDs is based on their activation of peroxisome proliferator-activated receptor- $\gamma$ (PPAR $\gamma$ ), a member of the nuclear receptor superfamily of transcription factors $(3,4)$. PPAR $\gamma$ receptor activation by TZDs ameliorates peripheral insulin sensitivity by promoting fatty acid uptake by adipocytes and adiponectin secretion, and by suppressing the inflammatory response, which

57 plays an important role in the development of insulin resistance. However, in spite of the beneficial effects of these molecules on insulin sensitivity and glucose homeostasis, many studies have evidenced that TZDs can lead to weight gain in several ways, including activation

60 of adipogenesis (5). Also, several studies have reported that a long-term treatment with TZDs

61 can be associated with an increased risk of cardiovascular events and cancer, thereby limiting

62 their use in favour of other treatment options (6-9). For example, pioglitazone, a TZD-drug in

63 clinical use, has been associated with an increased risk for bladder cancer in people with type 2

64 diabetes $(10,11)$. However, compared with pioglitazone, other TZD compounds such as

65 rosiglitazone, were not associated with an increased risk of bladder cancer, supporting the notion 66 that some adverse effects of TZDs are specific for each compound and not a class effect. In this 67 regard, troglitazone, first approved by FDA in 1997 (and later withdrawn), has been reported to 
68 cause massive hepatic necrosis, while both muraglitazone and rosiglitazone have been shown to

69 cause congestive heart failure and bone fractures (12). On the other hand, a significant

70 antiproliferative effect of TZDs on several types of cancer has been reported $(13,14)$, together

71 with the observation that some PPAR $\gamma$ agonists seem to contribute to improve the chemical

72 sensitivity of certain cancers to standard chemotherapeutic agents (15). Although clinical studies

73 supporting TZDs as anticancer agents are limited, studies in vitro, in cell cultures, and in vivo, in

74 animal models, well support the efficacy of TZDs in lung, breast and colon cancers (16). In these

75 cases, both PPAR $\gamma$-dependent and -independent mechanisms which may affect apoptosis, cell

76 cycle and differentiation have been hypothesized to explain the anti-tumor effects of these

77 compounds.

78 It is evident from the literature that the TZD moiety, which is essential for the activity, is linked

79 to the carbocyclic rings in all marketed drugs (17). Therefore, we conceptualized that including

80 N-heterocyclic systems like indolyl and indolinone moieties in the side chain of TZD derivatives,

81 could result in minor side-effects of medicinal products and increase specificity for specific

82 PPARs. In this endeavor, we synthesized indolyl/indolinone TZDs by adopting an improved (18)

83 and widely applicable synthetic method. 
91

92

93

94

95

MATERIALS AND METHODS

97

Synthesis of TZD analogues

98

99

100

101

102

103

104

105

106

107

108

109

110

111

112 determined in open capillary tubes in sulphuric acid bath for the crystalline products. TLC was

113 run on silica gel $\mathrm{G}$ and visualization was done using iodine or UV light. Infrared (IR) spectra 
114 were recorded using Perkin Elmer 1000 instrument in $\mathrm{KBr}$ pellets. ${ }^{1} \mathrm{H}$ NMR spectra were

115 recorded in DMSO- $\mathrm{d}_{6}$ using TMS as internal standard, by using $400 \mathrm{MHz}$ spectrometer. Mass

116 spectra were recorded on Agilent LC-MS instrument.

117

118 General procedure for preparation of 2

119 A mixture of TZD (1) $(10 \mathrm{mM})$ and DMF-DMA $(10 \mathrm{mM})$ was stirred at $100^{\circ} \mathrm{C}$ for $2 \mathrm{~h}$, giving

120 rise to a colourless solid that was separated from the reaction mixture. The solid was collected by

121 filtration, washed with hexane $(10 \mathrm{ml})$ and then dried. The crude product was recrystallized from

122 ethanol solvent to get pure 2.

123

124 General procedure for preparation of AC1-AC20

125 A mixture of $2(10 \mathrm{mM})$ and indole (3) $(10 \mathrm{mM})$ was refluxed for $1 \mathrm{~h}$ in acetic acid. At the end 126 of this period, a light yellow coloured solid separated out from the reaction mixture, which was

127 collected by filtration. The isolated solid was washed with hot water $(10 \mathrm{ml})$ and dried. The 128 product was recrystallized from a suitable solvent to obtain AC1.

General procedure for preparation of AC21-26

131 A mixture of TZD (1) (10 mM), isatin (4) (10 mM) and methanol (10 ml), followed by $40 \%$

132 aqueous $\mathrm{KOH}$, was refluxed for $30 \mathrm{~min}$. At the end of this period, solid separated out from the

133 reaction mixture, which was collected by filtration. The isolated solid was washed with methanol

$134(10 \mathrm{ml})$ and dried. The product was recrystallized from a suitable solvent to obtain AC21.

135

136 Spectral data of compounds are detailed in the Supplemental Appendix. 


\section{Cell cultures}

139 MCF-7 human breast cancer cells and PC3 human prostate cancer cells were obtained from the

140 American Type Culture Collection (LGC Promochem, Teddington, UK). Cells were maintained

141 in DMEM, supplemented with $2 \mathrm{mmol} /$ liter L-glutamine, $50 \mathrm{IU} / \mathrm{ml}$ penicillin, $50 \mu \mathrm{g} / \mathrm{ml}$

142 streptomycin, and 10\% fetal bovine serum $(19,20)$, and both viability and cell migration were

143 assessed as described elsewhere (20), in the presence of either home-made TZD compounds, or

144 commercially available rosiglitazone (rosiglitazone maleate, GSK Pharmaceuticals, Worthing, $145 \mathrm{UK})(20)$.

147 MTT Assay

148 The MTT assay is a colorimetric assay based on the transformation of tetrazolium salt by

149 mitochondrial succinic dehydrogenases in viable cells. By measuring mitochondrial function and 150 metabolic activity, the MTT test provides a reproducible quantitative indication of cellular

151 viability. In serum-free media, cultured MCF-7 and PC3 cells were tested for viability, using 12 $152 \mathrm{mM}$ MTT reagent (Sigma-aldrich, St. Louis, MO) for $2 \mathrm{~h}$ at $37^{\circ} \mathrm{C}$. Formazan crystals were 153 solved with $1 \mathrm{~mL}$ (12-wells plate) of an organic acid solution (40\% dimethylformamide, $2 \%$

154 glacial acetic acid, 16\% sodium dodecyl sulfate, $\mathrm{pH} 4.7$ ), in order to avoid phenol red

155 interference. Absorbance was read after 24, 48 and $72 \mathrm{~h}$ treatment at $540 \mathrm{~nm}$

157 Wound healing

158 The wound healing assay is a simple method to study cell migration and cell interactions in vitro.

159 Wound healing was performed seeding 500,000 cells/well in a 12-wells plate in order to reach 
160 confluence after $24 \mathrm{~h}$. Afterwards, scretches were made using sterile $200-\mu \mathrm{L}$ tips, then, wells

161 were washed three times with PBS and cells were treated with RPMI medium containing the

162 respective TZD compound (5 $\mu \mathrm{M}$ final concentration in DMSO 0.001\%). RPMI plus DMSO

163 alone $(0.001 \%)$ was used as vehicle control. Photos of the wound were taken at 4,8 and $12 \mathrm{~h}$.

164 Then, snapshots were analyzed with the ImageJ software (1) and percent of wound clousure was

165 calculated using the following equation:

$$
\% \text { wound closure }=\frac{\text { Area t0 }- \text { Area } \mathrm{tx}}{\text { Area } 0} \times 100
$$

\section{Protein extract and western blot analysis}

168 Total and nuclear cellular extracts were prepared as previously $(21,22)$, and Western blots were 169 performed on total and nuclear extracts from PC3 and MCF-7 cells, after 24, 48 and $72 \mathrm{~h}$

170 treatment, as reported elsewhere (23). Protein extracts were resolved on sodium dodecyl sulfate

171 polyacrylamide gel electrophoresis and electrotrasferred onto a $0.2 \mu \mathrm{m}$ PVDF membrane

172 (Merck-Millipore). Rabbit polyclonal antibodies anti-BCL-xL (cat. no 2762) and anti-cleaved

173 PARP (C-PARP) (cat. no 9541) were purchased from Cell Signaling Technology. Monoclonal

174 antibody anti- $\beta$ Actin (cat. no A2228) was from Sigma-Aldrich Inc (24). The resulting

175 immunocomplexes were visualized by enhanced chemiluminescence, and densitometric slot blot 176 analysis was performed by using the ImageJ software program.

\section{Statistical analysis}

179 Statistical significance was evaluated by Mann-Whitney test. $\mathrm{p}<0.05$ was considered significant.

180 All bar graph data shown are mean \pm S.E. 


\section{Molecular modelling studies}

183 The Schrödinger Suite was adopted for computing all theoretical investigations (25). The 3D

184 structure of AC-18, AC-20 and AC-22 were built using the Maestro GUI (26) and further

185 submitted to LigPrep version 3.9 tool (27) to take into account the most stable protomeric forms

186 at pH 7.4. The Protein Data Bank (28) crystallographic entry structure 2PRG (29) was prepared

187 by using the Protein Preparation Wizard tool (30). The molecular recognition evaluation was

188 carried out by means of Glide software ${ }^{[\mathrm{g}]}$ in combination with Schrödinger Induced Fit docking

189 (IFD) (31) protocol. The binding site of the target model was defined by means of a regular grid

190 box of about $64000 \AA \AA$ centered on the co-crystallized ligand. Docking simulations were

191 computed using Glide ligand flexible algorithm version 6.7 at standard precision (SP).

192 


\section{RESULTS}

\section{Inhibition of cell viability in MCF-7 and PC3 cells}

195 All the synthetic TZD-based compounds (from AC1 to AC26) were initially screened for their in

196 vitro effect on cell viability, using MTT assays in MCF7 and PC3 cells, that underwent treatment

197 with $5 \mu \mathrm{M}$ TZD analogues over a period from 24 to $72 \mathrm{~h}$ of exposure (Figure $3 \mathrm{~A}$ and $3 \mathrm{~B}$ ). As

198 observed both in MCF-7 cells and PC3 cells, not all compounds investigated produced the same

199 effect on cell viability, as compared with untreated control cells. In fact, whereas some of them

200 had no influence on this parameter at all time points of the 72-h period in both cell lines, a

201 decrease of cell viability (with slight difference among MCF-7 and PC3 cells) was observed with

$202 \mathrm{AC} 11, \mathrm{AC} 12, \mathrm{AC} 14, \mathrm{AC} 15, \mathrm{AC} 17, \mathrm{AC} 18, \mathrm{AC} 20, \mathrm{AC} 21, \mathrm{AC} 22, \mathrm{AC} 23, \mathrm{AC} 24, \mathrm{AC} 25$, and AC26

203 (Figure 3A and 3B).

204 Next, both cell types were incubated with increasing concentrations ( 1 to $33.3 \mu \mathrm{M}$ ) of each of the

205 twenty-six compounds individually to calculate $\mathrm{IC}_{50}$ values (Table I). Among all the compounds

206 evaluated, compounds AC18, AC20 and AC22 were found to be the most promising, showing a

$20750 \%$ reduction of cell viability in both PC3 and MCF-7 cells after 48 h exposure to $5 \mu \mathrm{M}$

208 concentration of each of the three drugs. However, whereas the inhibition of cell viability in

209 MCF-7 cells was already significant at $48 \mathrm{~h}$ with all three TZD analogues, no significant

210 inhibition of cell viability by these compounds was observed before $72 \mathrm{~h}$ incubation in PC 3 cells

211 (Figure 3A and 3B), thus suggesting some component of cell specificity amongst these synthetic

212 drugs.

213 To further evaluate the effect of AC18, AC20 and AC22 on cellular viability, we performed

214 MTT assays, in which the effect of each of these compounds on cell proliferation was compared

215 to that of untreated control cells, or cells treated with either the negative AC1 TZD compound, or 
$2165 \mu \mathrm{M}$ rosiglitazone, a potent oral antidiabetic drug, whose inhibitory role on cell viability has

217 been reported in vitro, in rat prolactin-secreting pituitary tumor cells (20). As shown in Figure

$2184 \mathrm{~A}$ and 4B, treatment of both MCF-7 and PC3 cells with $5 \mu \mathrm{M}$ of either AC18, AC20 or AC22

219 induced a significant decrease of cell viability as compared with control cells, which, in some

220 instances, was even more evident than that obtained with the same dose of rosiglitazone.

221 To further support the antiproliferative potential of AC18, AC20 and AC22, Western blot

222 analyses of BCL-xL were carried out in cell lysates from MCF-7 and PC3 cells. BCL-xL is an

223 important anti-apoptotic member of the BCL-2 protein family and a potent regulator of cell

224 death. While overexpression of BCL-xL in PC3 and MCF-7 cells has been reported to contribute

225 to the apoptosis-resistant phenotype of these cells in response to products with antitumor activity

$226(32,33)$, the reduction of Bcl-xL levels rendered these cells more sensitive to the drugs $(34,35)$,

227 thus reducing cell survival. As shown in Figue 4A and 4B, BCL-xL protein levels were reduced

228 in both MCF-7 and PC3 cells treated with the AC22 TZD compound, and this reduction

229 paralleled the decrease in cell viability (as monitored by the MTT assay). Additionally, as shown

230 in Figure 4B, treatment of PC3 cells with either AC18 or AC22 showed a better inhibition of cell

231 viability compared with cells treated with rosiglitazone, and also in this case a parallelism was

232 observed between cell viability and BCL-xL protein expression. Therefore, it is tempting to

233 hypothesize that the antiproliferative effect of these TZD compounds, including rosiglitazone, on

234 MCF-7 breast cancer cells and PC3 prostate cancer cells could be mediated, at least in part, by

235 the reduction in BCL-xL expression. These data were in agreement with the analysis of C-PARP,

236 a marker of apoptotic response (36), indicating that C-PARP expression was higher in MCF-7

237 and PC3 cells treated with the AC22 TZD compound than in rosiglitazone-treated cells. 
239 Effects of AC18, AC20 and AC22 on cell migration

240 The effects of AC18, AC20 and AC22 on cell migration were studied as well. To this end,

241 wound healing assays were performed in vitro with both MCF-7 and PC3 cells, either untreated

242 or treated with the synthetic TZD agonists, at $4 \mathrm{~h}$ time points (up to $12 \mathrm{~h}$ ). As shown in Figure

$2435 \mathrm{~A}$ and 5B, a significant inhibition of cell migration was observed in both MCF-7 and PC3 cells,

244 in the presence of compounds AC18, AC20 and AC22, as demonstrated by the decreased

245 migratory response of cells in response to wound healing. Also in this case, as for the MTT test,

246 the effect of all three compounds on cell migration was comparable or even superior than that of

247 rosiglitazone (Figure 5A and 5B), thereby indicating that these novel compounds may indeed

248 represent a new potential class of antiproliferative agents.

Theoretical binding affinity of compounds AC18, AC20, AC22 in the PPAR $\gamma$ active site in

251

252

253

254

255

256

257

258

259

260

261

\section{comparison to rosiglitazone}

In order to understand the molecular interactions of AC18, AC20 and AC22 into the PPAR $\gamma$ active site, ligand-target recognition studies were performed using the Glide Suite Docking package (31) and refined with the Schrödinger Induced Fit Docking (IFD) protocol (37) (Table S1, Supplemental Appendix). We selected the rosiglitazone/PPAR $\gamma$ crystal structure (PDB ID: 2PRG) (29) to carry out the docking simulations. We validated our protocol by calculating the Root Mean Square Deviation (RMSD) on the ligand $C \alpha$, thus demonstrating that the standard precision (SP) protocol was able to well reproduce the co-crystallized pose (rosiglitazone redocking RMSD value: $1.38 \AA$ ). The receptor grid center was specified from the bound ligand and the energy window for ligand conformational sampling was $2.5 \mathrm{kcal} / \mathrm{mol}$. In order to investigate the binding domain flexibility, the residues within $5.0 \AA$ from the ligand poses were refined 
262 using the Prime molecular dynamics module (38). A maximum of 20 poses was generated. The

263 docking results clearly indicated that all compounds are able to geometrically reproduce

264 rosiglitazone binding mode (Figure 6). Indeed, by analyzing the docking poses of all compounds,

265 we observed that the ligands were well accomodated into the active site of PPAR $\gamma$ by

266 establishing hydrogen bonds (HBs) between their carbonyl groups of the thiazolidine moiety

267 with H343, Y473 and H449 residues. Furthermore, the two water molecules located into the

268 binding site are involved in an indirect HB network between the compounds and the binding

269 pocket residues. However, it is interesting to note that for AC20 and AC22 the HB with R288 is

270 lost, while it is maintained by $\mathrm{AC} 18$. AC18 and $\mathrm{AC} 20$ share the same methoxyl group at position

2715 of their indole ring, while in $\mathrm{AC} 22$ it is substituted with a fluorine atom. Probably the ethyl

272 group on the amine of the thiazolidine ring, absent in AC18 and AC22 compounds, could be 273 responsible for a different geometry of the molecule.

275

276

277

278

279

280

281

282

283

284 


\section{DISCUSSION}

289 Insulin resistance is a hallmark of obesity and type 2 diabetes (39-41), and both these disorders

290 have an increased risk to develop some types of tumours, including breast, liver, colon, and 291 pancreatic cancers $(42,43)$. Many clinical trials have also documented that patients treated with

292 TZDs, while improving glycemic control and in spite of potentially drug-related adverse effects, 293 are less predisposed to these kind of cancers (3). The observation that some antidiabetic agents 294 such as TZDs $(3,13-15,44)$, as well as metformin (45-47), may exert an antiproliferative effect 295 on many cell types has triggered an intense research effort in the last years. Activation of PPAR $\gamma$ 296 by TZDs, by inducing apoptosis, growth arrest and cell differentiation in cancer cells, has been 297 proposed as an explanation for the anticancer activity of these compounds (16), together with 298 PPAR $\gamma$-independent mechanisms involving the proteosomal degradation of cyclins D1 and D3 299 (48), as well as the upregulation of PTEN/AMPK and the downregulation of the Akt/mTOR 300 signaling pathways (49). Further mechanisms of tumor suppression by TZDs may involve the 301 inhibition of important target genes, such as the vascular endothelial growth factor, $V E G F$, gene 302 (50), the PGE2 receptor gene (51), and the insulin receptor gene (44).

303 Nevertheless, our knowledge and understanding of how TZDs may exert anti-tumor effects still

304 remain not fully understood. This is made all the more difficult by the fact that non-univocal

305 results still exist on the antiproliferative activities of these drugs, either in in vitro studies or in 306 clinical investigations. In fact, whereas a strong antiproliferative effect was seen for TZDs in

307 several studies, no significant inhibition of cell proliferation of these compounds was observed in 
308 a number of other similar investigations from different research groups $(6,7,10)$. Conflicting

309 results, in this direction, have been reported also by meta-analysis of clinical trials, in which no

310 association was found between the use of TZDs and breast cancer risk among diabetic women

311 (52), whereas a protective effect of TZDs was associated with colorectal cancer in patients with

312 diabetes (53). Based on these considerations, there is a need to better understand the molecular

313 effects of TZDs and to develop safer and more effective synthetic ligands of PPARs. Herein, we

314 explored the antiproliferative effects of a series of newly synthesized TZD compounds, in which

315 the carbocyclic ring was replaced by the N-heterocyclic ring in an attempt to reduce their toxicity

316 while retaining their antiproliferative abilities at the same time. The replacement of the 2-

317 pyridinylamino terminal scaffold of rosiglitazone with the indolo ring prevents the potential

318 formation of $\mathrm{N}$-nitroso metabolites able to exert toxicity in vivo (54). Conversely, the indolo ring

319 is safer as typical scaffold of TRP sidechain. Therefore, by adopting a simple and tunable

320 synthetic strategy, twenty-six different TZD compounds were synthesized in moderate to high

321 yields. Among them, only three, designated AC18, AC20 and AC22, showed a significant

322 antiproliferative effect in two different human neoplastic cell lines, MCF-7 breast cancer cells

323 and PC3 prostate cancer cells, as demonstrated by cell viability assays, further supporting the

324 notion that different TZD compounds may display different effects on cell viability. In

325 agreement with previous observations with rosiglitazone (55), as revealed by Western blot

326 analysis, part of this antiproliferative effect was supported by apoptosis studies in both cell

327 models, showing downregulation of BCL-xL and upregulation of C-PARP following drug

328 treatment. As a next step towards their characterization, these same TZD molecules were also

329 effective in inhibiting cell migration and cell-to cell interaction, as shown by wound healing

330 assays. Furthermore, as the same molecule may present different efficacy and potency on 
331 different cancer cell lines, we showed that AC18 and AC22 were both more effective in MCF-7

332 and in PC3 cells than rosiglitazone, whereas AC20 was more powerful than rosiglitazone in

333 MCF-7, but not in PC3 cells. This can be partially due to the poor differentiation grade of PC3

334 cells (56) compared with MCF-7 cells. Also, PC3 cells are derived from a prostate cancer

335 metastasis, while MCF-7 cell strain retains many characteristics of the mammal epithelium cells,

336 such as the presence of estrogen receptors (57). However, since the antiproliferative activity of

337 these compounds has been assessed in vitro, we can only speculate about their safety in vivo, and

338 more studies are necessary to clarify this issue. In particular, further investigation in animal

339 models would confirm both efficacy and safety of the compounds herein proposed. Notably, the

340 more efficacious activity of $\mathrm{AC} 18, \mathrm{AC} 20$ and $\mathrm{AC} 22$ compounds, as compared to rosiglitazone in

341 an in vitro biological setting, was supported in in silico studies. This, in our opinion, represents a

342 strength of the present work, together with the fact that the present study is one of the few reports

343 in the literature analyzing anticancer properties of TZDs by wound healing assay. Conversely, as

344 limitation of this study, we should mention that we could not investigate the expression of

345 specific proliferation markers. Overall, the interest of TZDs as adjuvant therapy in cancer

346 treatment is still ongoing, and this is further supported by recent data indicating that also

347 noncanonical PPAR $\gamma$ agonists may modulate cancer cell sensitivity to chemotherapy for

348 therapeutic gain (58).

349

350 CONCLUSIONS

351 Herein, we propose a new set of three TZD analogues as potential anticancer agents. Although

352 more effort is needed to understand their efficacy and safety, we believe that these compounds

353 have the potential to be further developed as novel adjuvant tool for anticancer treatments. 


\section{REFERENCES}

356 1. Arcidiacono B, Iiritano S, Chiefari E, Brunetti FS, Gu G, Foti DP and Brunetti A:

357 Cooperation between HMGA1, PDX-1 and MafA is essential for glucose-induced insulin

358 transcription in pancreatic beta cells. Front Endocrinol 5: 237, 2015.

359 2. Hiatt WR, Kaul S and Smith RJ: The cardiovascular safety of diabetes drugs-insights from 360 the rosiglitazone experience. N Engl J Med 369: 1285-1287, 2013.

361 3. Janani C and Ranjitha Kumari BD: PPAR gamma gene - A review. Diabetes Metab Syndr:

$3629: 46-50,2015$.

363 4. Nanjan MJ, Mohammed M, Prashantha Kumar BR and Chandrasekar MJN:

364 Thiazolidinediones as antidiabetic agents: A critical review. Bioorg Chem 77: 548-567, 3652018.

366 5. Colca JR: The TZD insulin sensitizer clue provides a new route into diabetes drug

367 discovery. Expert Opin Drug Discov 10: 1259-70, 2015.

368 6. Lewis JD, Ferrara A, Peng T, Hedderson M, Bilker WB, Quesenberry CP, Vaughn DJ,

369 Nessel L, Selby J and Strom BL: Risk of bladder cancer among diabetic patients treated with $370 \quad$ pioglitazone. Diabetes Care 34: 916-922, 2011.

371 7. Hsiao FY, Hsieh PH, Huang WF, Tsai YW and Gau CS: Risk of bladder cancer in diabetic 372 patients treated with rosiglitazone or pioglitazone: a nested case-control study. Drug Saf 36: $373 \quad 643-649,2013$.

374 8. Gallagher AM, Smeeth L, Seabroke S, Leufkens HG and van Staa TP: Risk of death and 375 cardiovascular outcomes with thiazolidinediones: A study with the general practice research 376 database and secondary care data. PLoS One 6:e28157, 2011. 
377 9. Soccio RE, Chen ER and Lazar MA: Thiazolidinediones and the promise of insulin

378 sensitization in type 2 diabetes. Cell Metab 20: 573-591, 2014.

10. Tuccori M, Filion KB, Yin H, Yu OH, Platt RW and Azoulay L: Pioglitazone use and risk of bladder cancer: population based cohort study. BMJ 352: i1541, 2016.

11. Piccinni C, Motola D, Marchesini G, and Poluzzi E: Assessing the association of pioglitazone use and bladder cancer through drug adverse event reporting. Diabetes Care 34: 1369-1371, 2011.

12. Lipscombe LL, Gomes T, Lévesque LE, Hux JE, Juurlink DN and Alter DA: Thiazolidinediones and cardiovascular outcomes in older patients with diabetes. JAMA 298: 2634-2643, 2007.

13. Tseng CH: Rosiglitazone reduces breast cancer risk in Taiwanese female patients with type 2 diabetes mellitus. Oncotarget 8: 3042-3048, 2017.

14. Bolden A, Bernard L, Jones D, Akinyeke T and Stewart LV: The PPAR gamma agonist troglitazone regulates erk 1/2 phosphorylation via a PPAR $\gamma$-independent, MEK-dependent pathway in human prostate cancer cells. PPAR Res 2012: 929052, 2012.

15. Bunt SK, Mohr AM, Bailey JM., Grandgenett PM and Hollingsworth MA: Rosiglitazone and Gemcitabine in combination reduces immune suppression and modulates $\mathrm{T}$ cell populations in pancreatic cancer. Cancer Immunol Immunother 62: 225-236, 2013. Ther 6(A): 25-34, 2008. 
MG: Synthesis and aldose reductase inhibitory activity of 5-arylidene-2,4thiazolidinediones. Bioorg Med Chem 10: 1077-1084, 2002.

18. Riyaz S, Naidu A and Dubey PK: L-proline-catalyzed synthesis of novel 5-(1H-Indol-3-ylmethylene)-thiazolidine-2,4-dione derivatives as potential antihyperglycemic agents. Synthetic Commun 41: 2756-2762, 2011.

19. Iiritano S, Chiefari E, Ventura V, Arcidiacono B, Possidente K, Nocera A, Nevolo MT, Fedele M, Greco A, Greco M, Brunetti G, Fusco A, Foti D and Brunetti A: The HMGA1IGF-I/IGFBP system: a novel pathway for modulating glucose uptake. Mol Endocrinol 26: 1578-1589, 2012.

20. Gruszka A, Kunert-Radek J and Pawlikowski M: Rosiglitazone, PPAR- $\gamma$ receptor ligand, decreases the viability of rat prolactin-secreting pituitary tumor cells in vitro. Neuro Endocrinol Lett 26: 51-54, 2005.

21. Brunetti A, Foti D and Goldfine ID: Identification of unique nuclear regulatory proteins for the insulin receptor gene, which appear during myocyte and adipocyte differentiation. J Clin Invest 92: 1288-1295, 1993.

22. Brunetti A, Brunetti L, Foti D, Accili D and Goldfine ID: Human diabetes associated with defects in nuclear regulatory proteins for the insulin receptor gene. J Clin Invest 97: 258$262,1996$.

23. Bilotta FL, Arcidiacono B, Messineo S, Greco M, Chiefari E, Britti D, Nakanishi T, Foti DP and Brunetti A: Insulin and osteocalcin: further evidence for a mutual cross-talk. Endocrine 59: 622-632, 2018.

24. Bianconcini A, Lupo A, Capone S, Quadro L, Monti M, Zurlo D, Fucci A, Sabatino L, Brunetti A, Chiefari E, Gottesman ME, Blaner WS and Colantuoni V: Transcriptional 
422

423

424

425

426

427

428

429

430

431

432

433

434

435

436

437

438

439

440

441

442

activity of the murine retinol-binding protein gene is regulated by a multiprotein complex containing HMGA1, p54 nrb/NonO, protein-associated splicing factor (PSF) and steroidogenic factor 1 (SF1)/liver receptor homologue 1 (LRH-1). Int J Biochem Cell Biol 41: 2189-2203, 2009.

25. Software: Schrödinger, LLC, New York, NY. 2017.

26. Software: Maestro, Schrödinger, LLC, New York, NY. 2017.

27. Software: LigPrep, Schrödinger, LLC, New York, NY. 2017.

28. https://www.rcsb.org/

29. Nolte RT, Wisely GB, Westin S, Cobb JE, Lambert MH, Kurokawa R, Rosenfeld MG, Willson TM, Glass CK and Milburn MV: Ligand-binding domain of the human peroxisome proliferator activated receptor gamma. Nature 395: 137-143, 1998.

30. Software: Protein Preparation Wizard, Schrödinger, LLC, New York, NY. 2017.

31. Software: Glide, Schrödinger, LLC, New York, NY. 2017.

32. Li XY, Marani M, Mannucci R, Kinsey B, Andriani F, Nicoletti I, Denner L and Marcelli M: Overexpression of BCL-XL underlies the molecular basis for resistance to staurosporineinduced apoptosis in PC-3 Cells. Cancer Res 15: 1699-1706, 2001.

33. Okamoto Y, Obeid LM and Hannun YA: Bcl-xL interrupts oxidative activation of neutral sphingomyelinase. FEBS Lett 530:104-108, 2002.

34. Yu X, Yang L, Cairns MJ, Dass C, Saravolac E, Li X and Sun L-Q: Chemosensitization of solid tumors by inhibition of Bcl-xL expression using DNAzyme. Oncotarget 15: 9039$9048,2014$. 
443 35. Lin B, Li D and Zhang L: Oxymatrine mediates Bax and Bcl-2 expression in human breast $444 \quad$ cancer MCF-7 cells. Pharmazie 71: 154-157, 2016.

445 36. Kraus WL: Transcriptional control by PARP-1: chromatin modulation, enhancer-binding, 446 coregulation, and insulation. Curr Opin Cell Biol 20: 294-302, 2008.

447 37. Software: Induced Fit Docking protocol, Schrödinger, LLC, New York, NY. 2017.

448 38. Software: Prime, Schrödinger, LLC, New York, NY. 2017.

449 39. Pullinger CR, Goldfine ID, Tanyolaç S, Movsesyan I, Faynboym M, Durlach V, Chiefari E, 450 Foti DP, Frost PH, Malloy MJ, Brunetti A and Kane JP: Evidence that an HMGA1 gene 451 variant associates with type 2 diabetes, body mass index, and high-density lipoprotein 452 cholesterol in a Hispanic-American population. Metab Syndr Relat Disord 12: 25-30, 2014. 453 40. Greco M, Chiefari E, Montalcini T, Accattato F, Costanzo FS, Pujia A, Foti D, Brunetti A 454 and Gulletta E: Early effects of a hypocaloric, mediterranean diet on laboratory parameters 455 in obese individuals. Mediators Inflamm 2014: 750860, 2014.

456 41. Chiefari E, Foti DP, Sgarra R, Pegoraro S, Arcidiacono B, Brunetti FS, Greco M, 457 Manfioletti G, Brunetti A: Transcriptional regulation of glucose metabolism: the emerging 458 role of the HMGA1 chromatin factor. Front Endocrinol 9: 357, 2018 
459 42. Arcidiacono B, Iiritano S, Nocera A, Possidente K, Nevolo MT, Ventura V, Foti D, Chiefari

460 E and Brunetti A: Insulin resistance and cancer risk: an overview of the pathogenetic

461 mechanisms. Exp Diabetes Res 2012: 789174, 2012.

462 43. Talarico C, Dattilo V, D’Antona L, Menniti M, Bianco C, Ortuso F, Alcaro S, Schenone S, 463 Perrotti N and Amato R: SGK1, the new player in the game of resistance: chemo-radio 464 molecular target and strategy for inhibition. Cell Physiol Biochem; 39:1863-1876, 2016.

465 44. Costa V, Foti D, Paonessa F, Chiefari E, Palaia L, Brunetti G, Gulletta E, Fusco A and 466 Brunetti A: The insulin receptor: a new anticancer target for peroxisome proliferator467 activated receptor-gamma (PPARgamma) and thiazolidinedione-PPARgamma agonists. $468 \quad$ Endocr Relat Cancer 15: 325-335, 2008.

469 45. Anisimov VN: Metformin for cancer and aging prevention: is it a time to make the long 470 story short? Oncotarget 6: 39398-407, 2015.

46. Salani B, Del Rio A, Marini C, Sambuceti G, Cordera R and Maggi D: Metformin, cancer and glucose metabolism. Endocr Relat Cancer 21: R461-R471, 2014.

473 47. Lau Y-KI, Du X, Rayannavar V, Hopkins B, Shaw J, Bessler E, Thomas T, Pires MM, 474 Keniry M, Parsons RE, Cremers S, Szabolcs M and Maurer MA: Metformin and erlotinib $475 \quad$ synergize to inhibit basal breast cancer. Oncotarget 5: 10503-10517, 2014. 
476

477

478

479

480

481

482

483

484

485

486

48. Lu M, Kwan T, Yu C, Chen F, Freedman B, Schafer JM, Lee EJ, Jameson JL, Jordan VC and Cryns VL. Peroxisome proliferator-activated receptor gamma agonists promote TRAILinduced apoptosis by reducing survivin levels via cyclin D3 repression and cell cycle arrest. J Biol Chem 280: 6742-6751, 2005.

49. Han S and Roman J: Rosiglitazone suppresses human lung carcinoma cell growth through PPARgamma-dependent and PPARgamma-independent signal pathways. Mol Cancer Ther 5: 430-437, 2006.

50. Yang B, Lin P, Carrick KM, McNulty JA, Clifton LG, Winegar DA, Strum JC, Stimpson SA and Pahel GL: PPARgamma agonists diminish serum VEGF elevation in diet-induced insulin resistant SD rats and ZDF rats. Biochem Biophys Res Commun 334: 176-182, 2005.

51. Lebovic DI, Kavoussi SK, Lee J, Banu SK and Arosh JA: PPAR $\gamma$ activation inhibits growth and survival of human endometriotic cells by suppressing estrogen biosynthesis and PGE2 signaling. Endocrinology 154: 4803-4813, 2013.

52. Du R, Lin L, Cheng D, Xu Y, Xu M, Chen Y, Wang W, Bi Y, Li D, Lu J: Thiazolidinedione therapy and breast cancer risk in diabetic women: A systematic review and meta-analysis. Diabetes Metab Res Rev 34(2), 2018, doi: 10.1002/dmrr.2961.

53. Liu Y, Jin PP, Sun XC and Hu TT: Thiazolidinediones and risk of colorectal cancer in patients with diabetes mellitus: A meta-analysis. Saudi J Gastroenterol 24:75-81, 2018.

54. WHO, 1978. Environmental Health Criteria 5. Nitrates, Nitrites and N-nitroso Compounds. International Programme on Chemical Safety, World Health Organization, Geneva, Switzerland. 
497 55. Wang HY, Zhang Y, Zhou Y, Lu YY, Wang WF, Xin M and Guo XL: Rosiglitazone 498 elevates sensitization of drug-resistant oral epidermoid carcinoma cells to vincristine by 499 G2/M-phase arrest, independent of PPAR- $\gamma$ pathway. Biomed Pharmacother 83: 349-361, $500 \quad 2016$.

501 56. Tai S, Sun Y, Squires JM, Zhang H, Oh WK, Liang CZ and Huang J: PC3 is a cell line 502 characteristic of prostatic small cell carcinoma. Prostate 71: 16681679, 2011.

503 57. Holliday DL and Speirs V: Choosing the right cell line for breast cancer research. Breast $504 \quad$ Cancer Res. 13: 215, 2011.

505 58. Khandekar MJ, Banks AS, Laznik-Bogoslavski D, White JP, Choi JH, Kazak L, Lo JC, 506 Cohen P, Wong KK, Kamenecka TM, Griffin PR and Spiegelman BM: Noncanonical 507 agonist PPAR $\gamma$ ligands modulate the response to DNA damage and sensitize cancer cells to 508 cytotoxic chemotherapy. Proc Natl Acad Sci U S A 115: 561-566, 2018. 


\section{Figure Legends}

512

513 Figure 1: Synthesis strategy of TZD compounds

514

515 Figure 2: Structures of synthetized TZD analogues

516

517 Figure 3. Effects of TZD compounds (AC1-AC26) on cell viability. MTT assays were

518 performed in MCF7 (A) and PC3 (B) cells as reported in the Materials and Methods section.

519 Optical density (OD) was measured at $540 \mathrm{~nm}$, after 24, 48 and $72 \mathrm{~h}$ drug treatment. Results are

520 the mean \pm S.E. of triplicates from three independent experiments. ${ }^{*} \mathrm{p}<0.05,{ }^{*} \mathrm{p}<0.01$ relative to

521 untreated control cells $(\mathrm{C}=1)$, which received dosing vehicle alone $(0.001 \% \mathrm{DMSO})$. The

522 selected AC18, AC20 and AC22 TZD analogues, which were the most active in the inhibition of 523 cell viability in MTT assays, are shown.

Figure 4. Comparison between Rosiglitazone, AC18, AC20 and AC22 on cell viability. MTT

assays were performed in MCF7 (A) and PC3 (B) cells, either untreated or treated as indicated.

527 OD was measured at $540 \mathrm{~nm}$, after 24, 48 and $72 \mathrm{~h}$ drug exposure. Results are the mean \pm S.E. of

528 triplicates from three independent experiments. ${ }^{*} \mathrm{p}<0.05, * * \mathrm{p}<0.01,{ }^{*} * \mathrm{p}<0.001$ relative to either

529 untreated control cells $(\mathrm{C}=1)$, or cells treated with the non-effective $\mathrm{AC} 1$ compound.

530 Representative Western blots of BCL-xL and C-PARP from cell extracts of untreated and treated

531 MCF-7 and PC3 cells are shown in the autoradiograms, together with densitometric results of

532 BCL-xL and C-PARP proteins over $\beta$-Actin. All protein samples were processed at the same

533 time, under the same experimental conditions, PVDF membranes simultaneously exposed to 
534 ECL detection reagent, and immunocomplexes visualized by enhanced chemiluminescence in

535 the dark for $1 \mathrm{~min}$. Autoradiograms were generated by positioning the membranes in the same X-

536 ray cassette and thus exposed to the same film, in the same exposure conditions. Rosi,

537 rosiglitazone.

538

539 Figure 5. Inhibition of cell migration. Wound healing assays were carried out in MCF7 (A)

540 and PC3 (B) cells, using $200 \mu \mathrm{L}$ pipette tips to scratch confluent cells on the base of a 12-well

541 plate. Wound healing (\% wound closure) was measured and analyzed with the NIH ImageJ

542 software in both cell types, after 4, 8 and $12 \mathrm{~h}$ incubation with the compounds. Results are the

543 mean \pm SE of triplicates from three independent experiments. ${ }^{*} \mathrm{p}<0.05, * * \mathrm{p}<0.01,{ }^{* * *} \mathrm{p}<0.001$

544 relative to untreated (control) cells.

545

546 Figure 6. In silico Induced Fit Docking of TZD compounds into the PPAR $\gamma$ binding pocket.

547 Rosiglitazone (A) is shown as light green carbon sticks, while AC18 (B) AC20 (C) and AC22

548 (D) are shown as green, white and cyan ball-and-sticks, respectively. The residues located within

$5494 \AA$ from the bound ligand are displayed (gray sticks) and labeled. Hydrogen bonds, bad and

550 ugly contacts between the ligands and the enzyme residues or water molecules are depicted with

551 yellow, orange and red dashed arrows, respectively. 
Figure 1

Synthesis strategy of TZD compounds

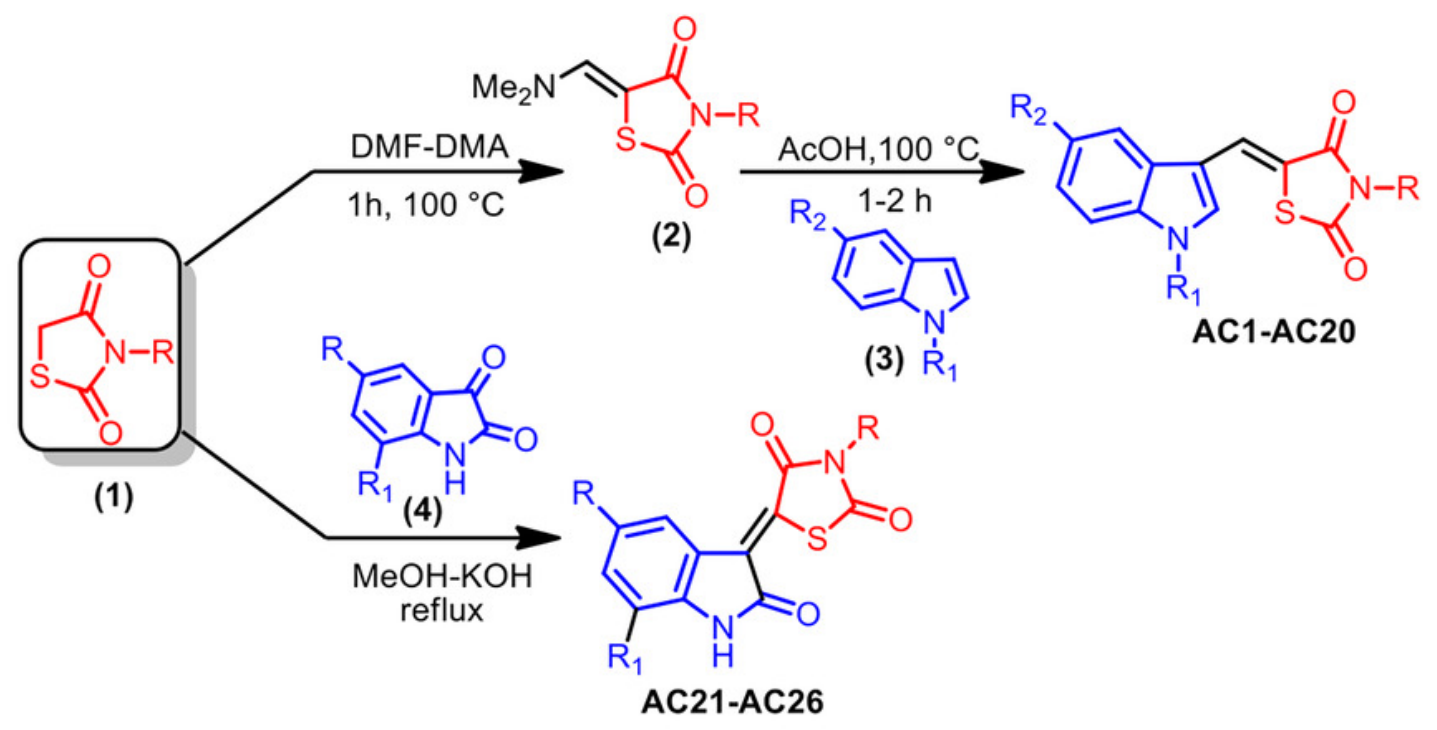


Figure 2

\section{Structures of synthetized TZD analogues}

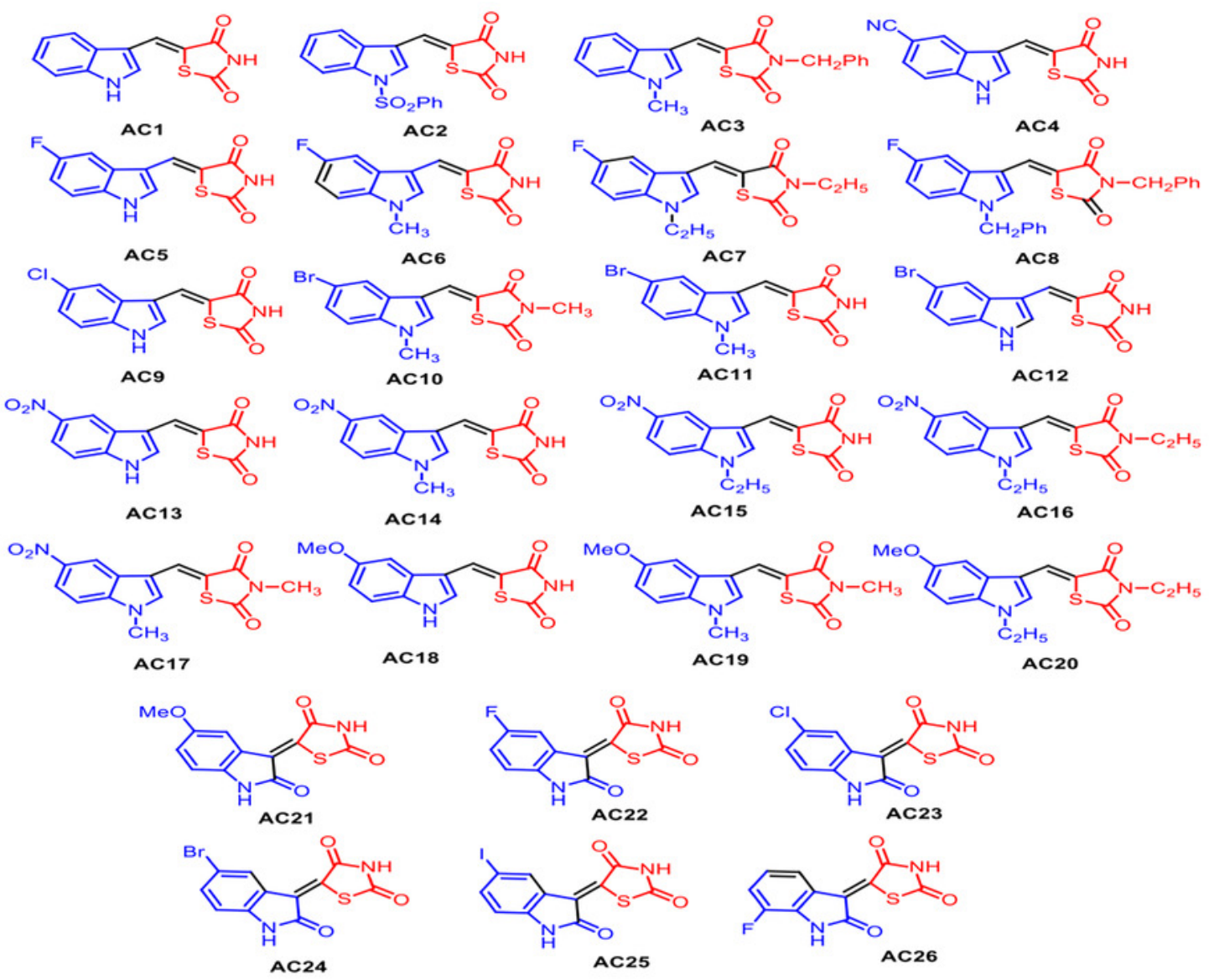




\section{Figure 3}

Effects of TZD compounds (AC1-AC26) on cell viability

MTT assays were performed in MCF7 (A) and PC3 (B) cells as reported in the Materials and Methods section. Optical density (OD) was measured at $540 \mathrm{~nm}$, after 24,48 and $72 \mathrm{~h}$ drug treatment. Results are the mean \pm S.E. of triplicates from three independent experiments. ${ }^{*} p<0.05,{ }^{* *} p<0.01$ relative to untreated control cells $(C=1)$, which received dosing vehicle alone $(0.001 \%$ DMSO).The selected AC18, AC20 and AC22 TZD analogues, which were the most active in the inhibition of cell viability in MTT assays, are shown. 


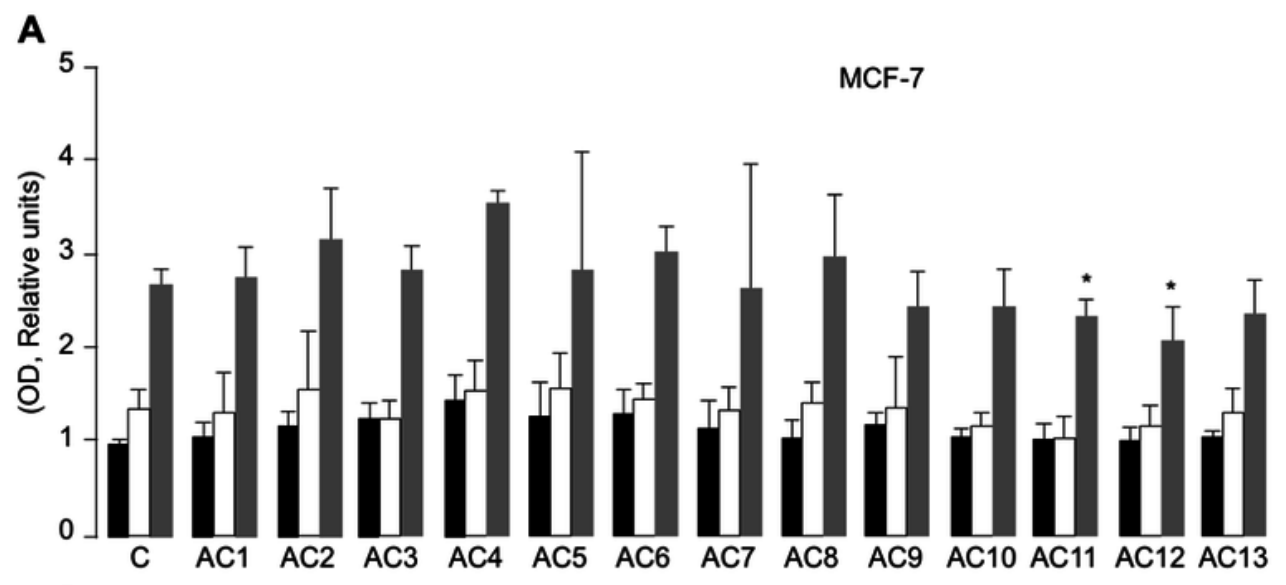

$24 \mathrm{hr}$

$\square 48 \mathrm{hr}$

$72 \mathrm{hr}$
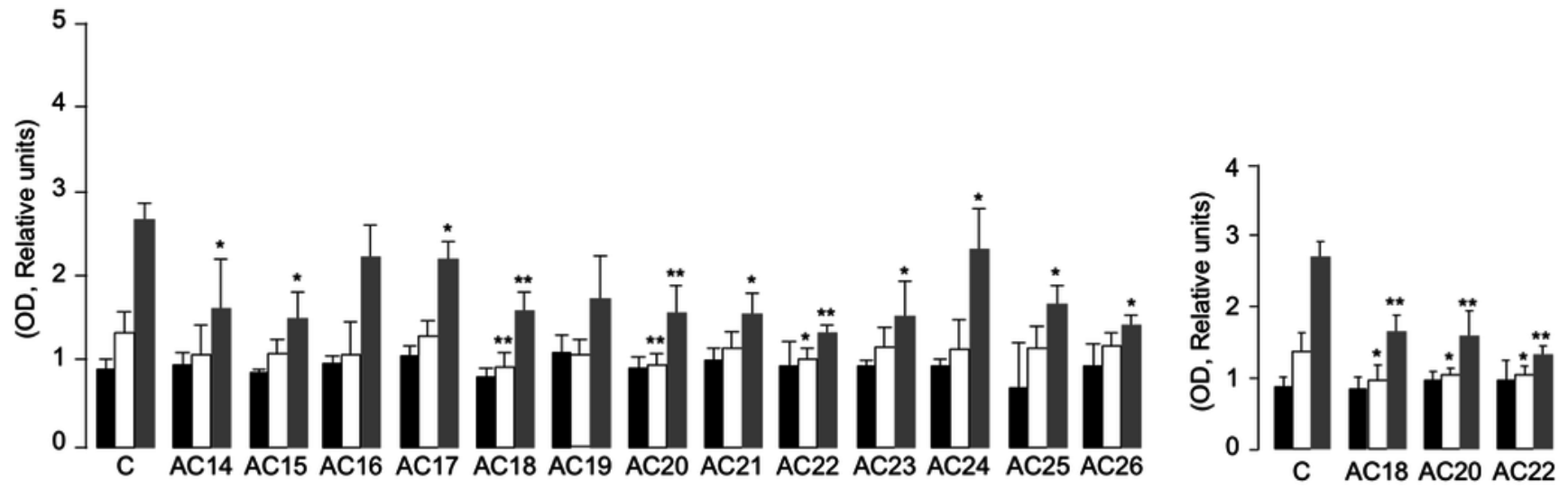

B

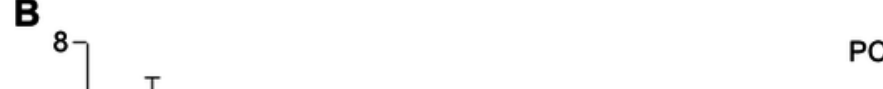

PC3

$24 \mathrm{hr}$

$\square 48 \mathrm{hr}$

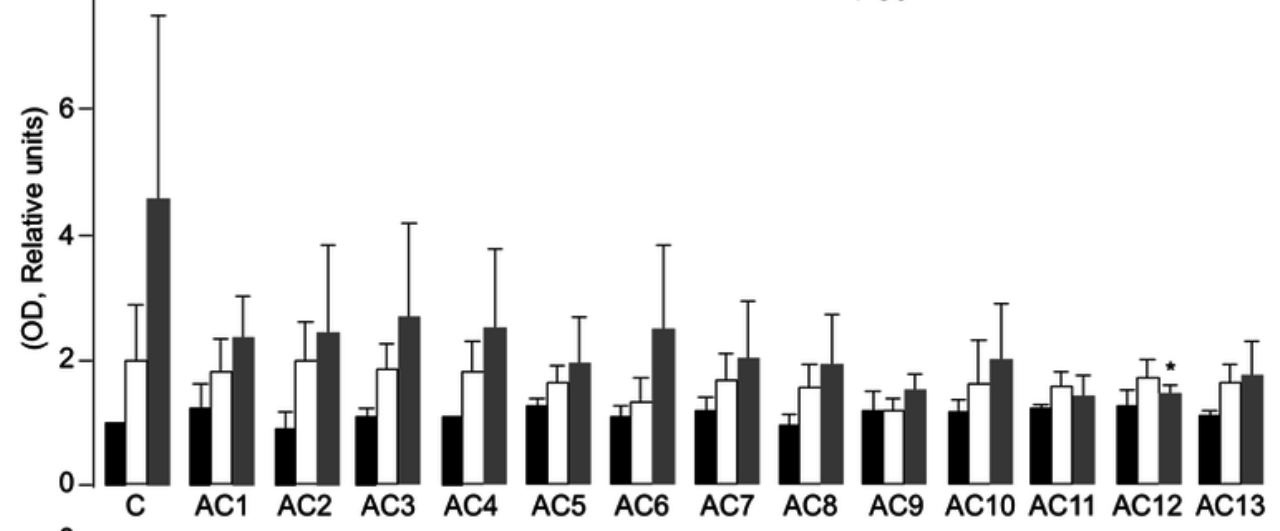

$72 \mathrm{hr}$
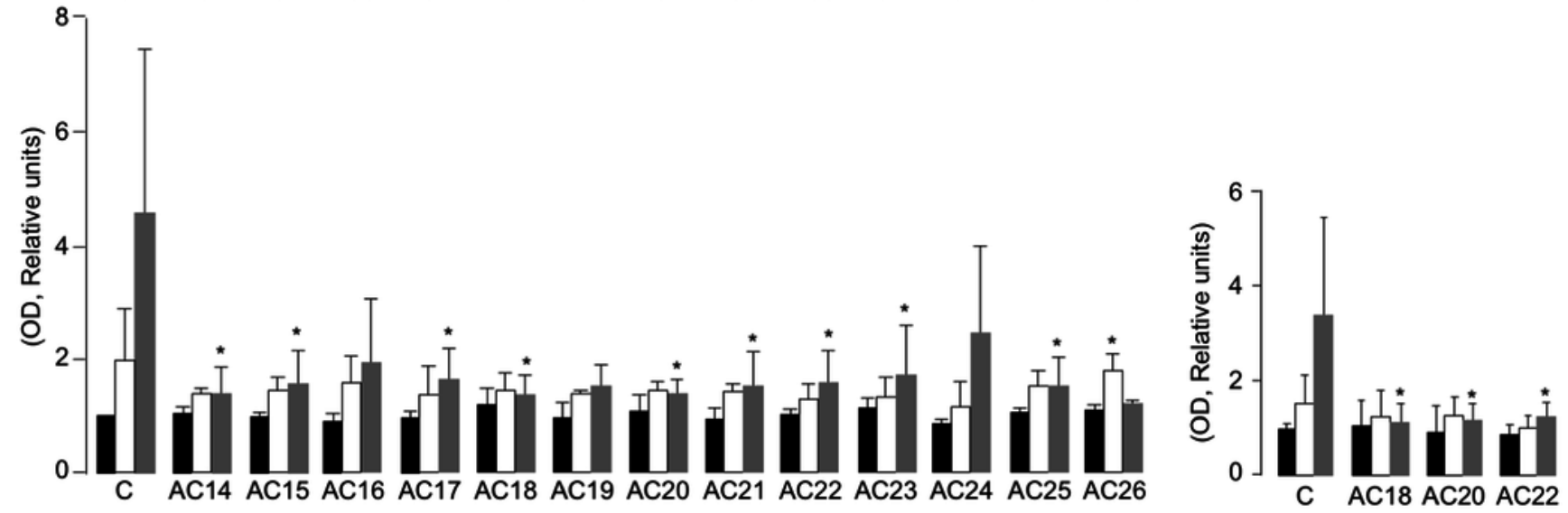


\section{Figure 4}

Comparison between Rosiglitazone, $\mathrm{AC} 18, \mathrm{AC} 20$ and $\mathrm{AC} 22$ on cell viability

MTT assays were performed in MCF7 (A) and PC3 (B) cells, either untreated or treated as indicated. OD was measured at $540 \mathrm{~nm}$, after 24,48 and $72 \mathrm{~h}$ drug exposure. Results are the mean \pm S.E. of triplicates from three independent experiments. ${ }^{*} p<0.05,{ }^{* *} p<0.01$, ${ }^{* * *} p<0.001$ relative to either untreated control cells $(C=1)$, or cells treated with the noneffective $A C 1$ compound. Representative Western blots of BCL-xL and C-PARP from cell extracts of untreated and treated MCF-7 and PC3 cells are shown in the autoradiograms, together with densitometric results of $\mathrm{BCL}-\mathrm{xL}$ and $\mathrm{C}$-PARP proteins over b-Actin. All protein samples were processed at the same time, under the same experimental conditions, PVDF membranes simultaneously exposed to ECL detection reagent, and immunocomplexes visualized by enhanced chemiluminescence in the dark for $1 \mathrm{~min}$. Autoradiograms were generated by positioning the membranes in the same X-ray cassette and thus exposed to the same film, in the same exposure conditions. Rosi, rosiglitazone. 

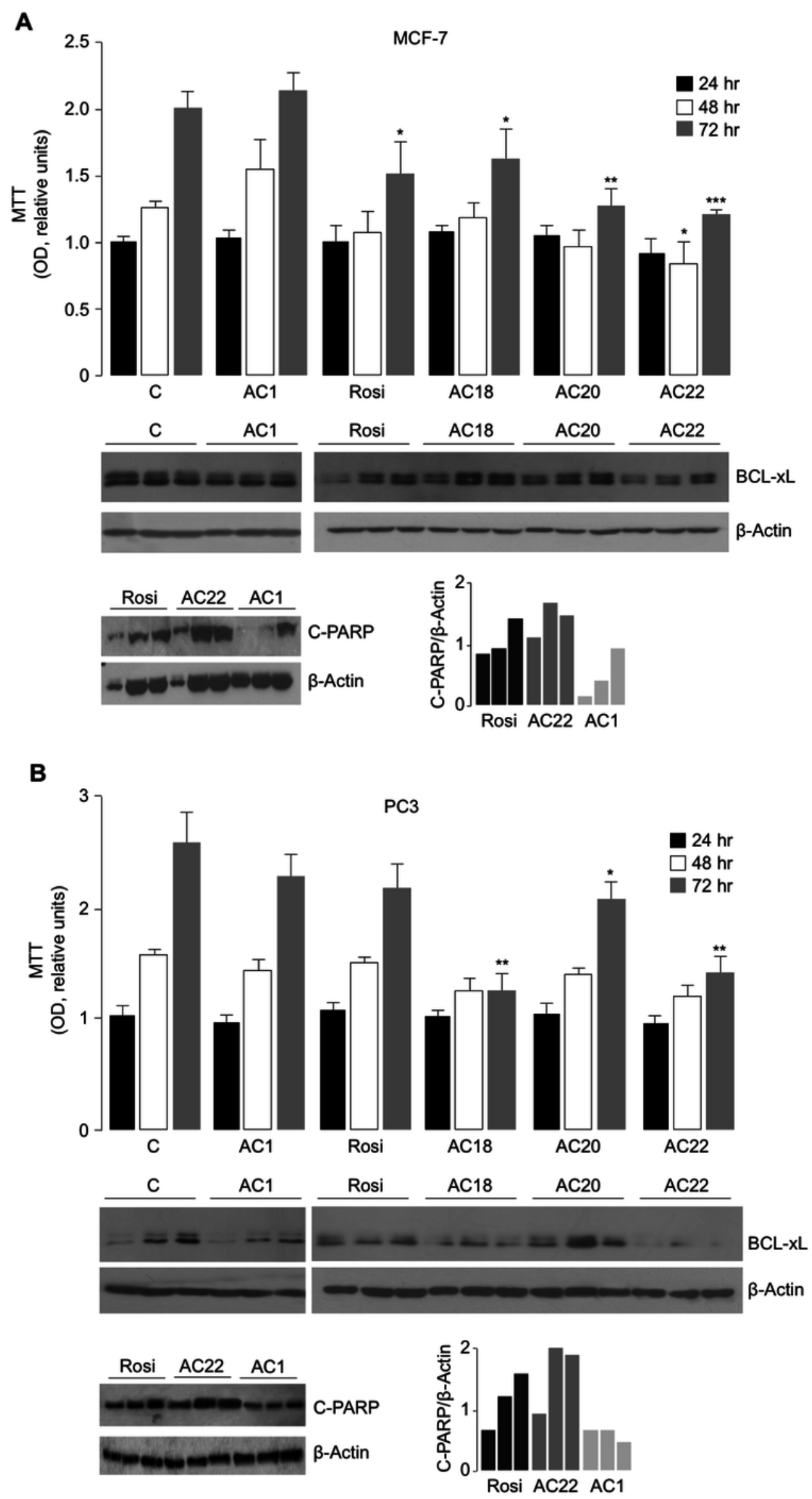


\section{Figure 5}

Inhibition of cell migration

Wound healing assays were carried out in MCF7 (A) and PC3 (B) cells, using $200 \mu \mathrm{L}$ pipette tips to scratch confluent cells on the base of a 12-well plate. Wound healing (\% wound closure) was measured and analyzed with the NIH ImageJ software in both cell types, after 4, 8 and $12 \mathrm{~h}$ incubation with the compounds. Results are the mean \pm SE of triplicates from three independent experiments. ${ }^{*} p<0.05,{ }^{* *} p<0.01,{ }^{* * *} p<0.001$ relative to untreated (control) cells. 
A
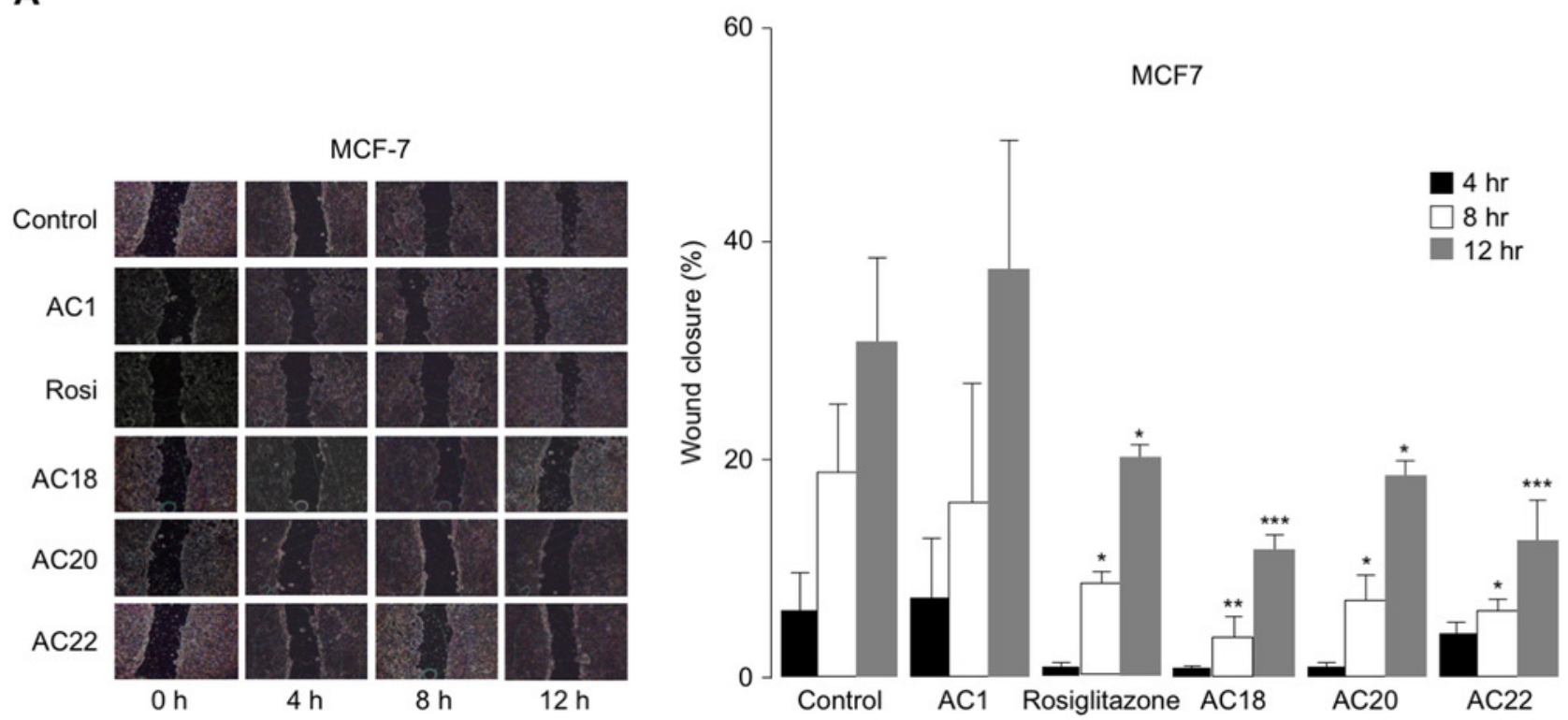

B

PC3
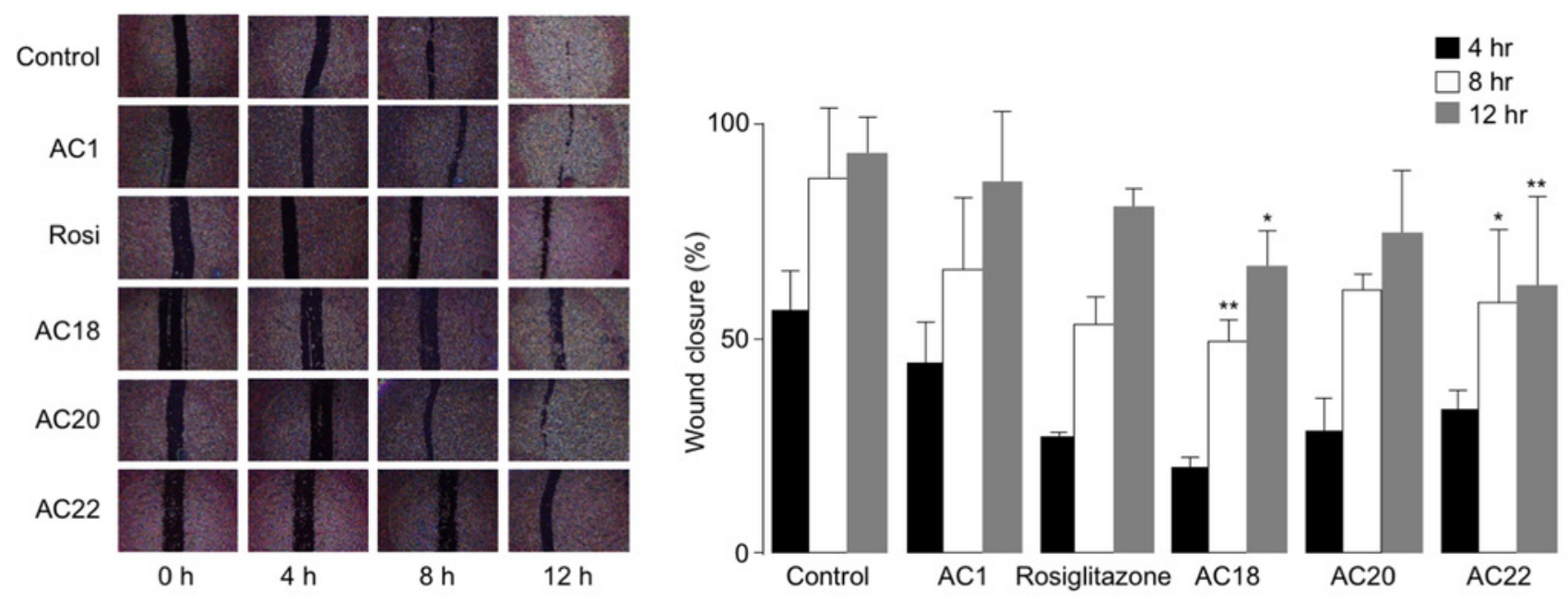


\section{Figure 6}

In silico Induced Fit Docking of TZD compounds into the PPARy binding pocket

Rosiglitazone (A) is shown as light green carbon sticks, while AC18 (B) AC20 (C) and AC22 (D) are shown as green, white and cyan ball-and-sticks, respectively. The residues located within $4 \AA$ from the bound ligand are displayed (gray sticks) and labeled. Hydrogen bonds, bad and ugly contacts between the ligands and the enzyme residues or water molecules are depicted with yellow, orange and red dashed arrows, respectively.

*Note: Auto Gamma Correction was used for the image. This only affects the reviewing manuscript. See original source image if needed for review.

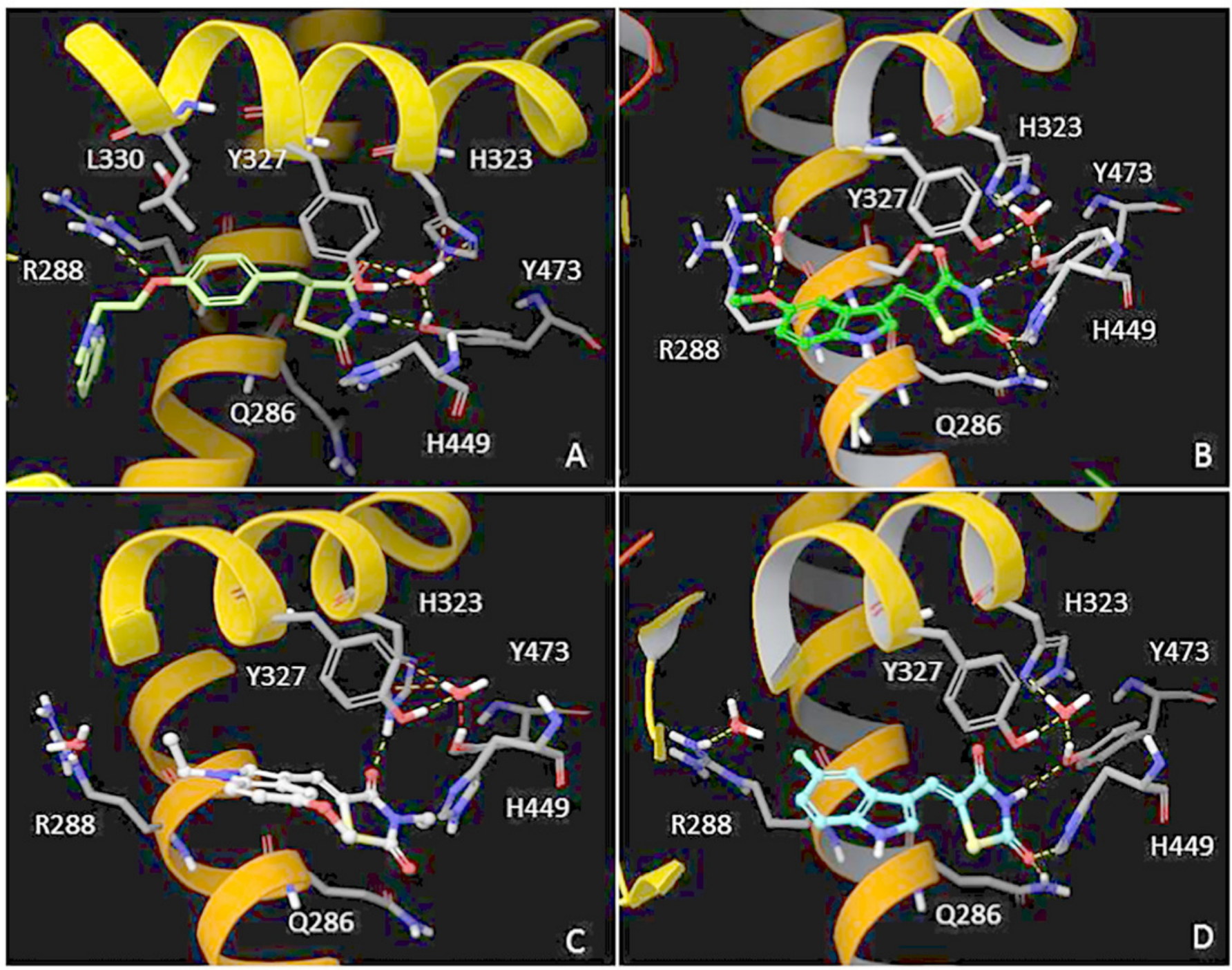




\section{Table $\mathbf{1}$ (on next page)}

$I C_{50}$ values of all the twenty-six compounds tested with MTT assay

Dose-response and time-course experiments were performed by exposing MCF-7 and PC3 cells to increasing doses $(1.0,3.3,5.0,10.0,33.3 \mu \mathrm{M})$ of each TZD compound for 24,48 and $72 \mathrm{~h} . \mathrm{IC}_{50}$ values are expressed as the concentration of each compound required to produce $50 \%$ inhibition of cell viability, in relation to time of exposure to the compound. NR, not responsive. 


\begin{tabular}{llllll}
\hline Compound & MCF-7 & PC3 & Compound & MCF-7 & PC3 \\
\hline 1 & $\mathrm{NR}$ & $\mathrm{NR}$ & 14 & $33.3 \mu \mathrm{M}(72 \mathrm{~h})$ & $33.3 \mu \mathrm{M}(72 \mathrm{~h})$ \\
2 & $\mathrm{NR}$ & $\mathrm{NR}$ & 15 & $\mathrm{NR}$ & $\mathrm{NR}$ \\
3 & $\mathrm{NR}$ & $\mathrm{NR}$ & 16 & $\mathrm{NR}$ & $\mathrm{NR}$ \\
4 & $\mathrm{NR}$ & $\mathrm{NR}$ & 17 & $33.3 \mu \mathrm{M}(72 \mathrm{~h})$ & $33.3 \mu \mathrm{M}(72 \mathrm{~h})$ \\
5 & $\mathrm{NR}$ & $\mathrm{NR}$ & 18 & $5 \mu \mathrm{M}(48 \mathrm{~h})$ & $5 \mu \mathrm{M}(48 \mathrm{~h})$ \\
6 & $\mathrm{NR}$ & $\mathrm{NR}$ & 19 & $\mathrm{NR}$ & $\mathrm{NR}$ \\
7 & $\mathrm{NR}$ & $\mathrm{NR}$ & 20 & $5 \mu \mathrm{M}(48 \mathrm{~h})$ & $5 \mu \mathrm{M}(48 \mathrm{~h})$ \\
8 & $\mathrm{NR}$ & $\mathrm{NR}$ & 21 & $33.3 \mu \mathrm{M}(72 \mathrm{~h})$ & $33.3 \mu \mathrm{M}(72 \mathrm{~h})$ \\
9 & $\mathrm{NR}$ & $\mathrm{NR}$ & 22 & $5 \mu \mathrm{M}(48 \mathrm{~h})$ & $5 \mu \mathrm{M}(48 \mathrm{~h})$ \\
10 & $\mathrm{NR}$ & $\mathrm{NR}$ & 23 & $33.3 \mu \mathrm{M}(72 \mathrm{~h})$ & $33.3 \mu \mathrm{M}(72 \mathrm{~h})$ \\
11 & $\mathrm{NR}$ & $\mathrm{NR}$ & 24 & $\mathrm{NR}$ & $\mathrm{NR}$ \\
12 & $33.3 \mu \mathrm{M}(72 \mathrm{~h})$ & $33.3 \mu \mathrm{M}(72 \mathrm{~h})$ & 25 & $33.3 \mu \mathrm{M}(72 \mathrm{~h})$ & $33.3 \mu \mathrm{M}(72 \mathrm{~h})$ \\
13 & $\mathrm{NR}$ & $\mathrm{NR}$ & 26 & $33.3 \mu \mathrm{M}(72 \mathrm{~h})$ & $33.3 \mu \mathrm{M}(72 \mathrm{~h})$ \\
\hline
\end{tabular}

